\title{
季節変化を考慮した差画像を用いた 洪水災害被災地域の同定 \\ IDENTIFICATION OF FLOOD DISASTER AREA USING THE DIFFERENTIAL IMAGE WITH THE SEASONAL CHANGES CONSIDERATIONS
}

\author{
児島利治 \\ Toshiharu KOJIMA \\ 正会員＼cjkstart博 (工） 京都大学助手 防災研究所水災害研究部門 （广611-0011＼cjkstart京都府宇治市五ヶ庄）
}

\begin{abstract}
The satellite images are expected to use for monitoring and identification of the disaster area. A differential image is basic method to distinguish the surface change. It is considered that the differential image is useful to extract the disaster area in which surface condition changed between before and after disaster. However the differential images have not been used efficiently due to seasonal change. This paper proposed a new method to produce a differential image using fine and coarse resolution image. Sensors with coarse spatial resolution can acquire the images with higher temporal frequency. However such coarse image does not have enough spatial resolution to investigate flood disaster area. On the other hand, fine spatial resolution sensor can not acquire the images with higher temporal frequency. The new method simulates the fine resolution image which has the surface reflectance when coarse image was acquired (just before disaster or no seasonal change), using the linear mixture model. New method can exclude the effect of seasonal change and has a good capability to identify only flood disaster area
\end{abstract}

Key Words : Landsat-7/ETM+, NOAA/AVHRR, interpolated fine resolution image, seasonal change, linear mixture model

1. はじめに

2002年8月31日〜9月1日にかけて朝鮮半島を横断した 台風0215号（Rusa）は，韓国全土に豪雨による洪水氾濫 や土砂災害を引き起こした ${ }^{1)}$. 被災地域が広範囲に及び, また道路等の寸断により現地調査が困難な災害において 被災状況の全容を迅速に把握するためには，遠隔地から 観測可能かつ広範囲に観測できる衛星画像が有効と考え られている. 一方, 衛星画像の利用方法の一つに, ある 一定期間の前後に撮影された2枚の衛星画像から差画像 を生成し，地表面状態が変化した箇所を抽出する手法が ある. 差画像は土地利用の経年変化の解析等に有効であ り, 衛星画像の基本的な利用方法として広く用いられて いる.

差画像を災害調查に適用する場合，災害前と災害後に 撮影された画像を用いて災害前後で変化の生じた箇所を 被苂地とする手法が一般的である．しかし，差画像の洪 水災害被災地同定への適用には次のような問題点が挙げ られる。

\section{（1）雲の影響}

災害調査にしばしば用いられる光学式のセンサは，雲 を透過して地表面が撮影できないという特徴があり, 被 災地域に雲がかかっていると良好な画像が撮影できない. 洪水災害の場合，災害発生時には豪雨が発生している場 合が多いこと, 洪水災害が多発する季節には雲が多く発 生することから, 洪水災害発生直前直後の良好な衛星画 像の入手は非常に困難である.

\section{（2）撮影頻度}

Landsat-7の回帰日数（同じ場所に戻って来る日数） は17日であり，撮影頻度は17日に1回の撮影である．衛 星が直上に飛来する直前に災害が発生した場合を除き, Landsat衛星で災害発生直後の画像を撮影することは難 しい. SPOT衛星の回帰日数は26日である. しかし, SPOT 衛星は撮影依頼を受けて斜めに観測することにより衛星 直下以外の地域の撮影が可能である. また複数の同型機 を用いることにより，他の撮影依頼と競合しなければ， ほぼ毎日災害地域の撮影を行うことが可能である.この ため, SPOT衛星は, Landsat衛星と比較して災害直後の 画像の入手は比較的容易である. 近年の例では, 有珠山 
や三宅島の噴火において撮影された衛星画像のうちSPOT 画像が非常に多いこと年からも災害後のSPOT画像の入手 は, 他の衛星に比べて比較的容易であることが分かる. しかし，SPOT画像は依頼を受けて撮影を行うため，撮影 依頼の無い地域では，1年間に1シーンも撮影されない場 合もあり，災害直前に関しては，定期的に撮影を行って いるLandsat画像に対して撮影頻度は非常に疎であると 言える.

\section{（3）地表面の季節変化}

災害直前画像の入手は極めて困難なため，災害発生前 から $1 ， 2$ 年程度前に撮影された画像を差画像作成に用 いる場合が多い，その際，洪水災害の発生した6月～9月 の画像は，災害の前年度であっても雲のために良好な画 像が撮影されておらず，秋〜春の画像が災害前画像に用 いられる場合が多い，そのため，差画像作成の際，災害 による地表面変化だけでなく，画像間の季節変化による 地表面変化も抽出されるという問題点がある.

\section{（4）解決策の提案}

洪水災害調査に対する，高分解能衛星画像の入手に関 して以下のことが言える.

・ 災害直前の画像の入手は, ほとんど不可能

- 災害前の同季節の画像の入手は非常に困難

・ 季節を問わなければ，災害前の画像の入手は可能

・ 災害直後の画像の入手は比較的容易

災害前の画像の入手が非常に困難な最も大きな原因は 撮影頻度が低いことである. Landsat，SPOT等の高分解 能画像の通常時撮影頻度は，2回弱／月であり，雲の無 い良好な画像が入手できる可能性は極めて低い，ところ が，NOAA画像のように毎日撮影されていれば，災害直前 の画像もしくは前年度の同じ季節の画像の入手は容易で ある. しかし，撮影頻度の高いNOAA画像は，空間分解能 は $1.1 \mathrm{~km}$ と粗く，炎害調查への利用は困難である。 そこ で，本研究では，空間分解能は粗いが撮影頻度の高い画 像 (NOAA) と，空間分解能は高いが撮影頻度の低い画像 （Landsat）を組み合わせて災害前画像と同じ季節の地 表面状態を再現した災害前画像を生成し，差画像生成， 被災地同定への適用可能性について検討を行う。

\section{2. 対象地域と使用データ}

Landsat-7/ETM+画像とNOAA/AVHRR画像を用いる．ETM+ はLandsat/TMの後継機種であり，TMと同じく $30 \mathrm{~m}$ 分解能 のバンド1〜4（可視〜近赤外），バンド5，7（中間赤 外）と $60 \mathrm{~m}$ 分解能の熱赤外バンド(バンド6) 及び， $15 \mathrm{~m}$ 分 解能のパンクロマティックバンド (バンド8) を持って
表-1 衛星画像リスト

\begin{tabular}{ccc}
\hline & Landsat-7/ETM $^{+}$ & NOAA/AVHRR \\
\hline Path-Row & $115-35$ & \\
Date (before) & Nov. 19, 2001 & Sep. 16, 2001 \\
Date (after) & Sep. 3, 2002 & \\
\hline
\end{tabular}

いる. NOAA画像は，空閒分解能 $1.1 \mathrm{~km}$ であり，バンド1 は可視(赤)，バンド2は近赤外，バンド3〜 5は熱赤外に 観測波長域を持つ気象観測衛星である. 空間分解能は粗 いが観測頻度が高いため, 全球の植生のモニタリング等 に用いられる。

対象地域は，韓国中央部の茂朱(Muju) 周辺とし，表-1 に示す画像を解析に用いた。

\section{3. 解析手法}

（1）高分解能画像を利用した低分解能画像の高分解能化 手法

本研究で提案する手法では, 必要な時期（災害直前又 は災害発生時と同じ季節）の地表面の輝度情報を持つが， 地表面状態の空間的に詳細な情報を持たない画像（低分 解能画像；NOAA）と，空間的に詳細な地表面情報を持つ が，必要な時期の輝度情報を持たない画像（高分解能画 像 ; Landsat-7）を組み合わせて，空間的に詳細かつ必 要な時期の輝度情報を持つ画像を生成する. 高空間分解 能画像と低分解能画像を組み合わせて，低分解能画像の 高空間分解能化に関しては様々な研究がなされている. 稲村は，Landsat画像の可視・近赤外バンドの情報を用 いて，低分解能の熱赤外バンドを高空間分解能化する手 法を示した ${ }^{3)}$. Ph. Puyou-Lascassiesらは, Linear mixture modelを基礎とし，低分解能画像からLandsat画 像の土地被覆分類カテゴリ毎の輝度值を推定し，その推 定精度をカテゴリ毎に評価した4)。本研究で提案した手 法は，Ph.Puyou-Lascassiesらの提案した手法とカテゴ リ分解を行う点でほとんど同じ概念である. 本手法の基 礎概念は以下の通りである.

Landsat画像を用いて教師無し分類を行い，対象域は $p$ 個のカテゴリに分けられるとする．NOAA画像の各画素と 教師無し分類結果は図-1のように対応付けられる. 図一 1 では, NOAA画像の $i$ 番目の画素に対応するカテゴリ $j(j=1 . . p)$ は, カテゴリ1〜4である.

ここで, NOAA画像の $i$ 番目の画素の輝度值を $R_{i}(i=1 . . . m$; $m$ はNOAA画像の画素数) とし, $i$ 番目のNOAA画像画素内の カテゴリjの面積を $A_{i j}$ としたとき, 以下の式が成立する.

$$
\frac{1}{A} \sum_{j}^{p} A_{i} r_{i j}=R_{i}
$$

ここで, $r_{i j}$ は墦目のNOAA画素内のカテゴリjの平均輝度 


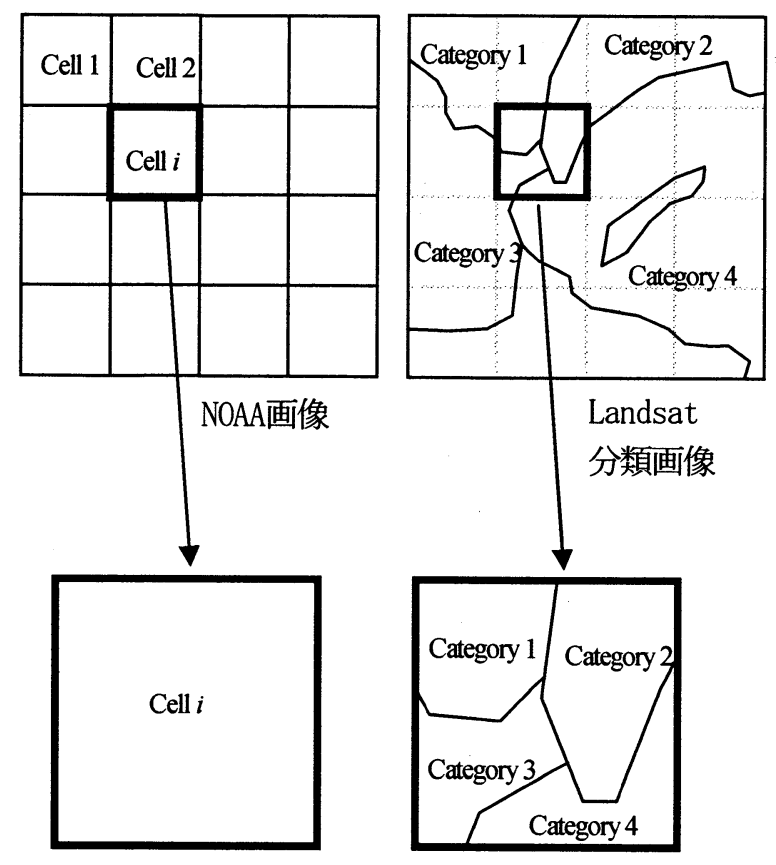

図-1 NOAA画像の画素 $i$ とLandsat分類画像のカテゴリ毎の面積 の関係図.

值，Aは墦目のNOAA画像の画素全体の占める面積，すな わち $1 \mathrm{~km}^{2}$ である. 図-1の例ではカテゴリは1〜4なので以 下のように示される. $A_{i 1} \sim A_{i 4}$ はそれぞれ画素i内におい てカテゴリ1〜4の占める面積, $r_{i 1} \sim r_{i 4}$ はそれぞれ画素 $i$ 内 におけるカテゴリ1〜4の平均輝度值である.

$$
\frac{1}{A}\left(A_{i 1} r_{i 1}+A_{i 2} r_{i 2}+A_{i 3} r_{i 3}+A_{i 4} r_{i 4}\right)=R_{i}
$$

カテゴリごとの平均輝度值 $r_{i j}$ は，ある程度近い画素であ

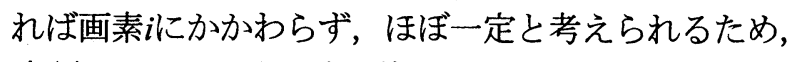
式(1)は以下のように書き換えることができる.

$$
\frac{1}{A} \sum_{j}^{p} A_{i j} r_{j}=R_{i}
$$

ここで, $r_{j}$ は, 画素i近傍のカテゴリjの平均輝度值. NOAA 画像の画素值 $R_{i}$ と分類カテゴリの面積率が $A_{i j} / A$ が既知で あれば, 式(3) は以下のような連列方程式を解くことに よりカテゴリごとの平均輝度值 $r_{j}$ が求まる.

$$
\begin{gathered}
A_{11} r_{1}+A_{12} r_{2}+\cdots+A_{1 j} r_{j}+\cdots+A_{1 p} r_{p}=R_{1} \\
A_{21} r_{1}+A_{22} r_{2}+\cdots+A_{2 j} r_{j}+\cdots+A_{2 p} r_{p}=R_{2} \\
\vdots \\
A_{i 1} r_{1}+A_{i 2} r_{2}+\cdots+A_{i j} r_{j}+\cdots+A_{i p} r_{p}=R_{i} \\
\vdots \\
A_{m 1} r_{1}+A_{m 2} r_{2}+\cdots+A_{m j} r_{j}+\cdots+A_{m p} r_{p}=R_{m}
\end{gathered}
$$

最後に分類画像においてカテゴリ $j$ に分類された画素 の輝度值を全て $r_{j}$ とすることで, 高分解能画像が生成さ れる. したがって, 生成された高分解能画像では, 同じ カテゴリに含まれる領域け同じ輝度値を持つ.

本手法では, 分類カテゴリの面積率 $A_{i j} / A$ を求めるため にLandsat画像の教師無し分類図を用い， $R_{i}$ には，NOAA 画像の画素值を用いる. 式(4)における係数 $r_{j}$ の推定には, QR分解による線形回帰分析手法を用いた.

本研究では, 高分解能画像では撮影されていない時期 の情報を補間するという意味から, 以上の手法で生成さ れた高分解能化画像を高分解能補間画像と呼ぶこととす る.

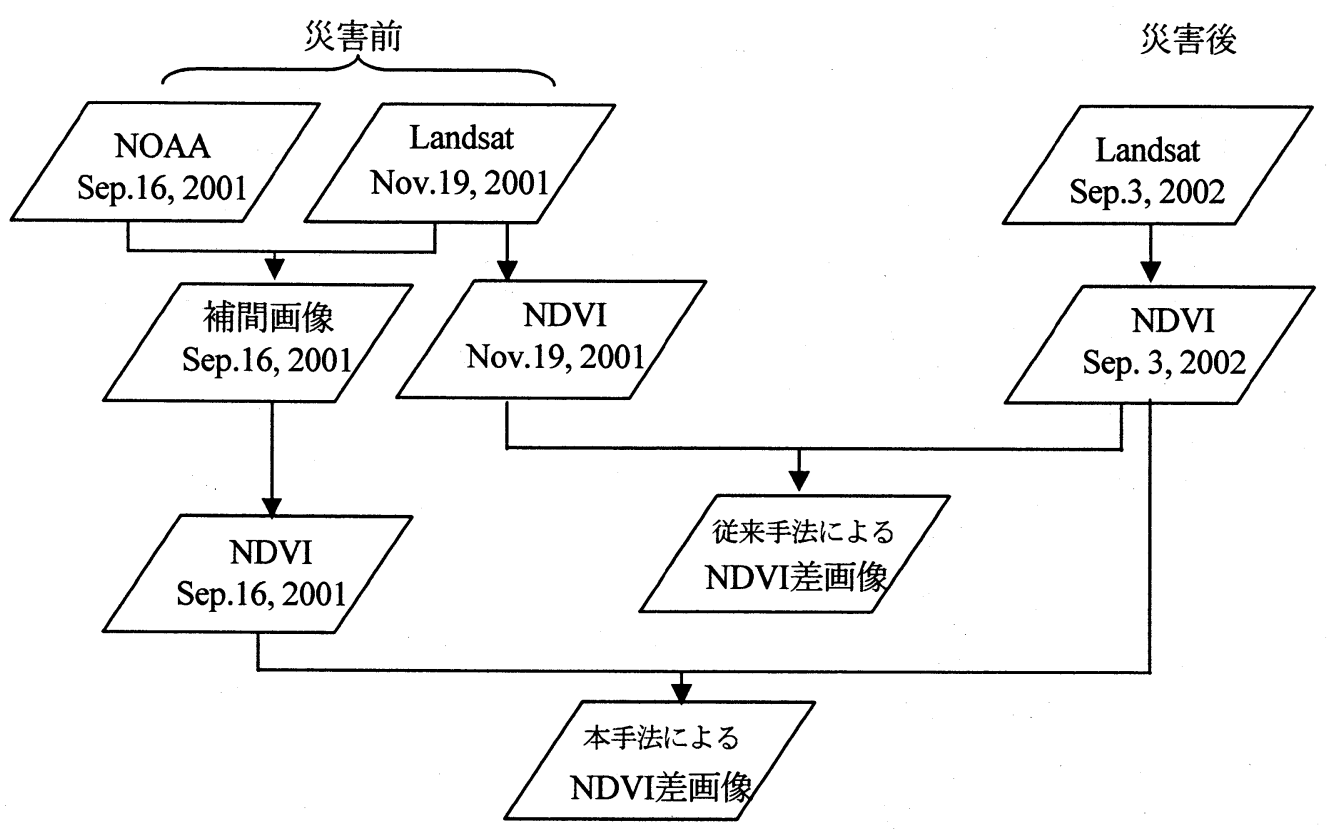

図-2 差画像生成フロー. 


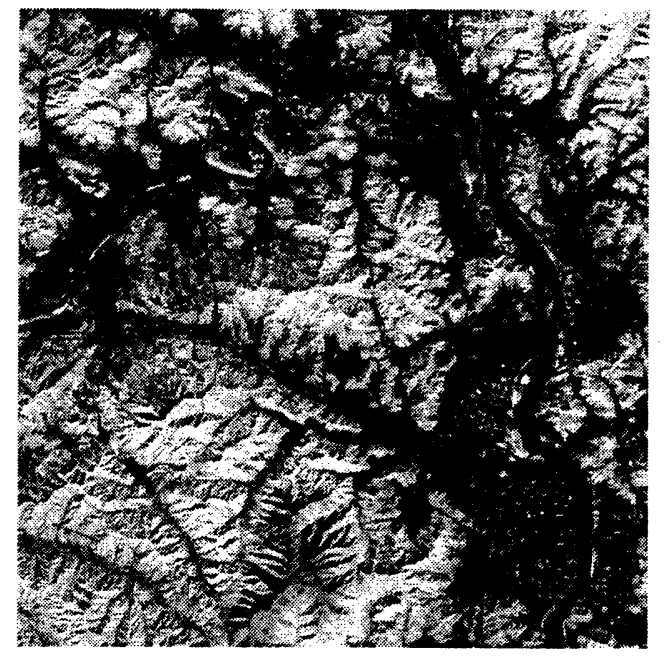

図-3災害前のNDVI画像(Landsat-7 ; 2001/11/19撮影).

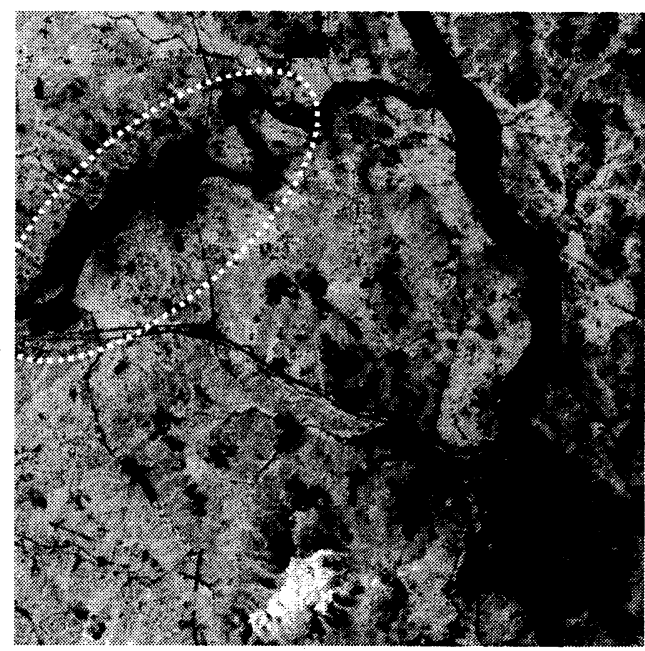

図-4 災害後のNDVI画像 (Landsat-7；2002/9/3撮影)。

\section{（2）差画像生成手順}

図-2に差画像生成手順を示す．図中の数字は衛星画像 撮影日またはその画像が示す地表面状態の日付である. 災害後のLandsat画像と同じ季節（9月）に撮影された NOAA画像と災害前Landsat画像を用いて，災害後Landsat 画像と同じ季節の地表面情報を持った補間画像を生成す る. 補間画像と災害後画像から生成したNDVI画像を用い てNDVI差画像を生成し，被災地同定を行う．比較のため に，従来通りの手法である災害前Landsat画像と災害後 Landsatから生成したNDVI画像からも差画像を生成し, 被災地同定を試みる．差画像は災害前画像の画素值から 災害後画像の画素值を引くことにより生成される（式 (5)) .

$$
P d_{i}=P b_{i}-P a_{i}
$$

ここで, $P d_{i}$ : 差画像の画素値, $P b_{i}$ : 災害前画像の画素 值, $P a_{i}$ : 災害後画像の画素值である.

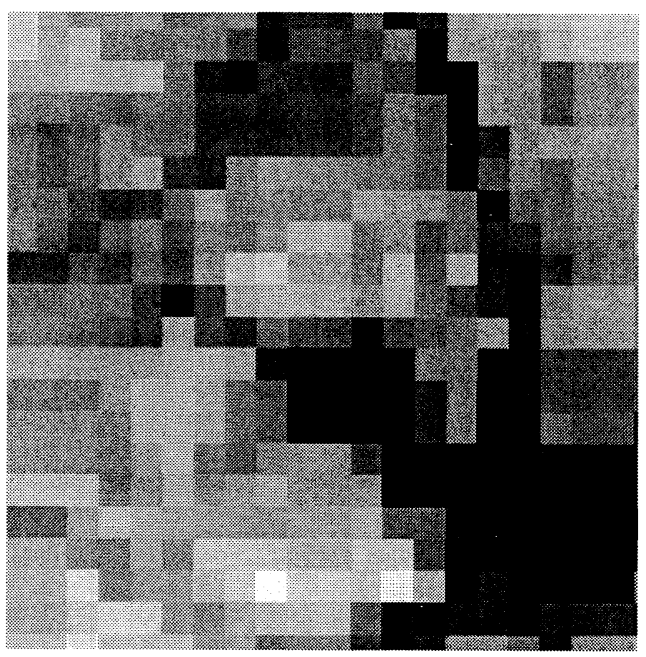

図-5 災害前のNDVI画像 (NOAA；2001/9/16撮影)。

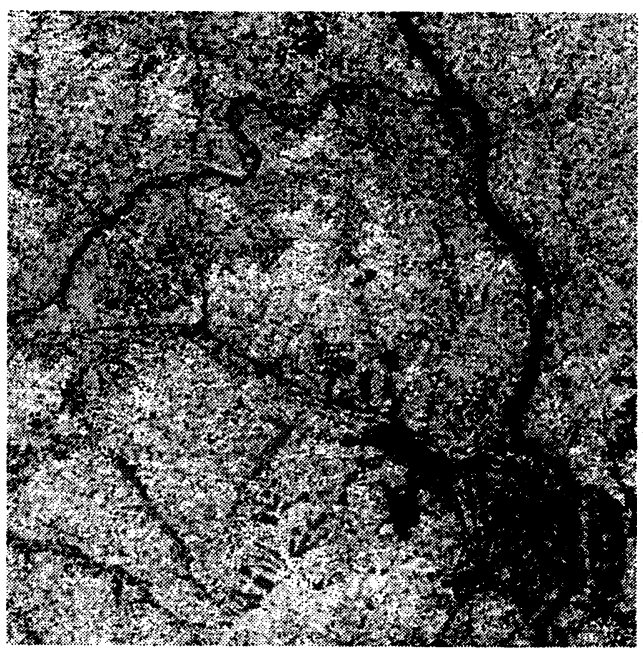

図-6＼cjkstart補間画像から生成したNDVI画像.

\section{4. 結果と考察}

\section{（1）補間画像の生成}

図-3，図-4に，災害前後のLandsat-7/ETM+画像から生 成したNDVI (Normalized Difference Vegetation Index) 画像を示す. NDVIは植物の活力度を示寸指標で, 式(6) を用いて算出される.

$$
\mathrm{NDVI}=\frac{N I R-V S}{N I R+V S}
$$

ここで, $N I R$ : 近赤外バンドの輝度值, $V S$ : 可視バンド の輝度值である. Landsat-7画像を用いた場合, 近赤外 バンドとしてバンド4, 可視バンドとしてバンド3（赤） を用いたNDVI画像が一般的に用いられる. NOAA画像の場 合は, 近赤外バンドとしてバンド2, 可視バンドとして バンド1が用いられる(図-5)。図-3において明るく表現 


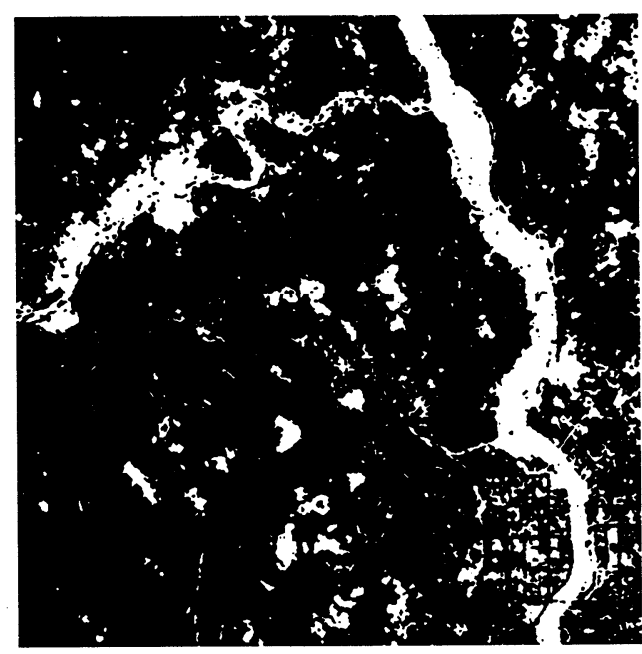

図-7補間画像を用いたNDVI差画像

(Sep. 16, 2001 - Sep. 3, 2002).

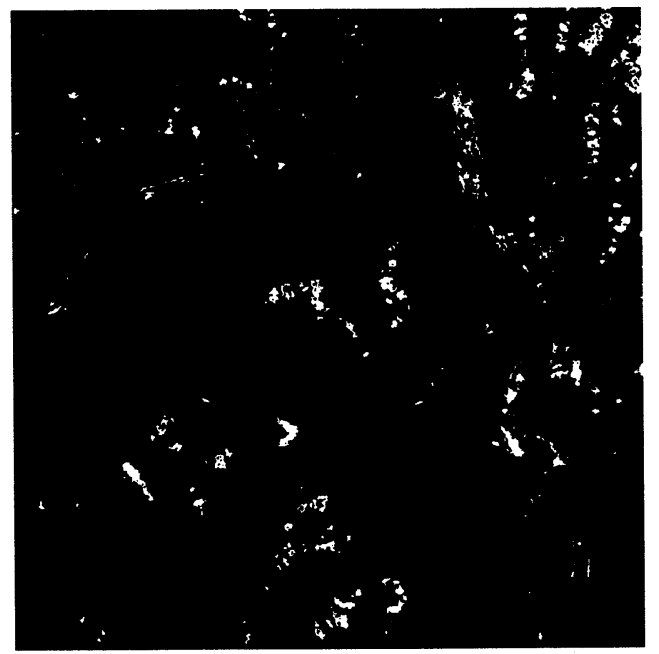

図-8 従来手法によるNDVI差画像

(Nov. 19, 2001 - Sep. 3, 2002).

されている領域のほとんどは森林域である. 図-3, 図-4 の両画像において常に暗い右下の領域は都市域である. 都市域では9月，11月の両季節ともに植生に乏しいため, NDVI画像では常に暗く表現されている. 図-3において河 川の両岸に広がる暗い領域は, 耕作地（水田）である. 刈り入れ後の時期（11月）である図-3では暗く表現され ているが，刚り入れ前の画像（9月；図-4）では明るく 表現されている. 図-4において楕円で囲まれた暗い領域 が洪水氾濫によって浸水した水田である. 図一6に補間画 像から生成したNDVI画像を示寸. 図-5のNOAA画像と比較 して, 空間分解能が極めて向上していることが分かる. 図-6において耕作地は明るく表現されており，2001年9 月の刚り入れ前の地表面状態をよく再現している.

\section{（2）差画像の生成亡被災地の同定}

図-7に本研究で提案した補間画像を用いて生成した NDVI差画像を示す. 図-7は, 図-6から図-4を引いて生成

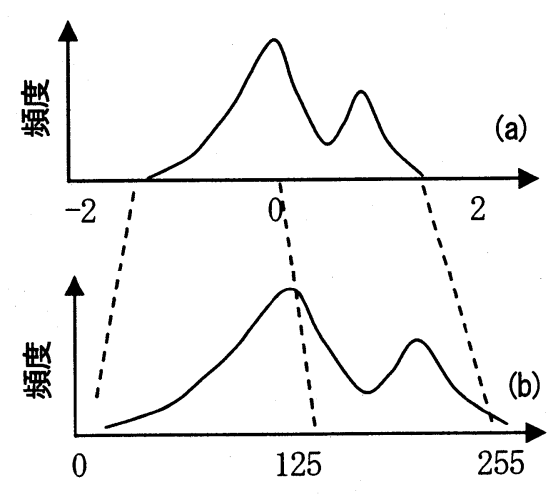

図-9ヒストグラムストレッチの図示（図-7;（a） NDVI差画 像の画素值の頻度分布，（b）0-255值への画像強調）.

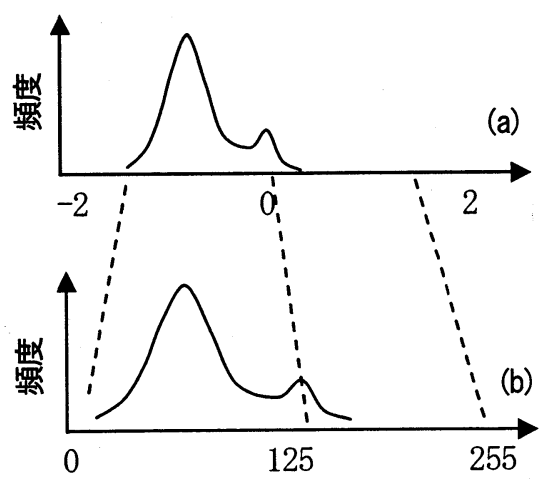

図-10 ヒストグラムストレッチの図示（図-8；（a）NDVI差 画像の画素值の頻度分布，（b）0-255值へ画像強調）.

された差画像である. 図-4で確認できた氾濫域や増水し た河川等が白くはっきりと確認できる．耕作地や河川敷 の植生が存在し，NDVI值が高い領域において，洪水氾濫 が発生し, 土砂や増水のため植生がダメージを受け, NDVIの值が減少した領域が明るく表現されている.

図-8は，従来行われてきた災害前後に撮影された Landsat画像から直接生成されたNDVI差画像である（図一 3一図-4）. 図-7を生成した場合と同様に災害後画像で は被災地は氾濫水や土砂のため, NDVI值 (植生活力度) は低い，しかし図-8の生成に利用された災害前画像 (図-3）は，11月撮影のため画像全体が災害後よりも植 物活力度が低く, NDVI差画像ではほとんどの画素值が負 となっている.

図-9，図-10は，それぞれ図-7，図-8の表示画像生成 の際のヒストグラムストレッチを図示している. 図-7で は, 季節変化が無いため, 差画像内のほとんどの画素値 は変化の無い0付近を示し，洪水汇濫によって被災した 一部の水田のみ正の值（植生が減少）を示す（図-9(a) 参照) . 画像表示のために行うヒストグラムストレッチ のイメージ図が図-9(b)である. 画像の一部分は 125 以上 の明るい色を示す画素值分布となっていると考えられる. 図-10は, 図-8のヒストグラムストレッチのイメージ図 


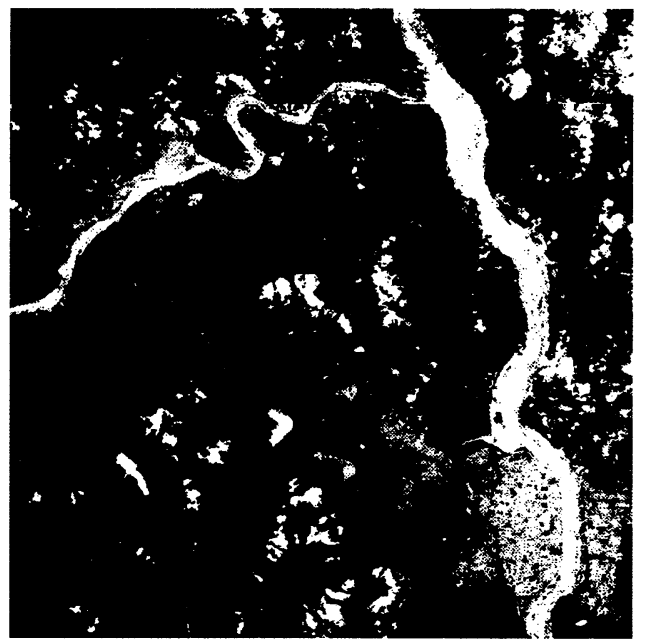

図-11 従来手法によるNDVI差画像（ヒストグラムストレッ 千調整後；Nov. 19，20 Sep. 3，2002).

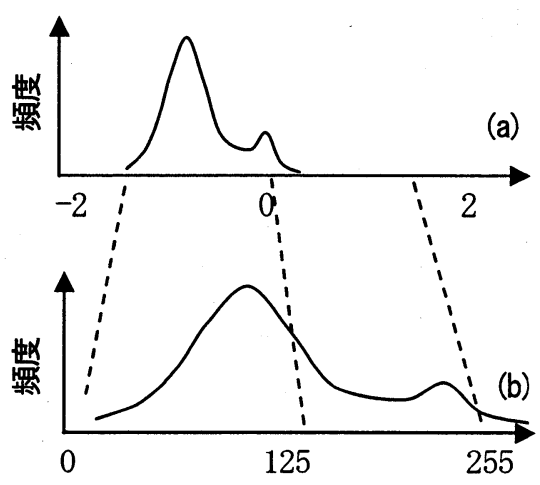

図-12 ヒストグラムストレッチの図示（図-11；（a） NDVI差 画像の画素値の頻度分布，(b) 0-255值へ画像強調）。

である. 図-8では，ほとんどの画素值が負（植生が増 加；11月～$\rightarrow 9$ 月）であるため, 図-7と同様のヒストグラ ムストレッチを行うとほとんどの画素が125以下の暗い 表示となる. そのため, 図-8はほとんどの領域が黒で表 示され，被災地の確認ができない．

図-11は，被災地が確認できるように，ヒストグラム ストレッチを調整した画像である. 画像左上隅の被災地 は確認できるが，その形状は不明瞭である. また, 右下 の都市域が白く表示されている. 図-11は，図-12のイ メージ図で図示しているように，都市域等の植物活力度 にあまり変化の無い箇所や実際に葉植物活力度が若干減 少した領域等のNDVI差画像の画素値で0周辽の値も255周 辺まで強調して表示している. そのため, 撮影時期によ る植生の変化がほとんど無いはずの都市域が白く表示さ れるというエラーが発生している.

\section{5. おわりに}

2002年に韓国で発生した台風RUSAによる洪水災害を例
にとり, 衛星画像の洪水被災地同定一の適用可能性の検 討を行った. 本研究で得られた知見は以下の通りである.

- 高分解能画像と低分解能画像を組み合わせて, 任意 の時期（低分解能画像の撮影された時期）の高分解 能補間画像を作成する手法を提案した. 高分解能補 間画像により, 撮影頻度の低い高分解能画像が撮影 されていない時期の詳細な地表面状態を推測するこ とが可能となった.

- 災害前後の画像から輝度値の差画像を作成し, 地表 面の変化を抽出する手法においては季節変化の影響 が問題点であった．差画像の生成に，高分解能補間 画像を用いることにより季節変化の影響を排除し, 熟練者の詳細な判読を必要とせず, 被災地域の同定 が可能となった.

災害調查への衛星画像の利用の期待は非常に大きいが, 1）観測頻度の問題から災害時に良好な画像の入手が困 難なこと，2）季節変化の影響により災害前後の画像の 比較から被災地を同定するには熟練を要することが主な 原因となって, 実際の現場での利用は少なく, 事後解析 が中心であった。

本研究で提案した高分解能補間画像を用いた差画像 は，季節変化の影響を排除し，熟練者の判読を必要とせ ずに被災地域の同定が可能となり, 災害調査一の衛星画 像のさらなる利用の一助となると期待される.

謝辞 : 本研究の一部は, 平成14年度科学研究費特別研究 促進費「2002年朝鮮半島における豪雨洪水土砂災害に関 する調查研究」（研究代表者: 寶 馨京都大学教授）の 補助を受けて行われたものである.ここに記して謝意を 表します。

\section{参考文献}

1) 牛山素行 · 寶馨・立川康人・近森秀高 : 2002年 8 月 31 日 9 月1日の台風15号による韓国の豪雨災害, 自然災害科学, Vol.21, No. 3, pp. 299-309, 2002.

2) 衛星リモートセンシング推進委員会, 宇宙開発事業団, (財) リモート・センシング技術センター: 有珠山噴火一平 成12年（2000年）一宇宙加の篗測と解析結果，pp. 9-1, 2000.

3) 稲村 実: 高空間分解能可視・近赤外画像を利用する低分 解能熱赤外画像の空間分解能改善, 電子情報通信学会誌, Vol. J71-A, No. 2, pp. 497-504, 1988.

4) $\mathrm{Ph}$. Puyou-Lascassies, A. Podaire and M. Gay: Extracting crop radiometric responses from simulated low and high spatial resolution satellite data using a linear mixing model, International Journal of Remote Sensing, Vol. 15, No. 18, pp. 3767-3784, 1994. 